\title{
Hypolipidemic and antioxidant activities of Asparagus racemosus in hypercholesteremic rats
}

\author{
N. P. Visavadiya, A.V.R.L. Narasimhacharya
}

\begin{abstract}
Objective: To study the efficacy of Asparagus racemosus in reducing the cholesterol levels and as an antioxidant in hypercholesteremic rats.

Materials and Methods: Hypercholesteremia was induced in normal rats by including $0.75 \mathrm{~g} \%$ cholesterol and $1.5 \mathrm{~g} \%$ bile salt in normal diet and were used for the experiments. Dried root powder of Asparagus racemosus was administered as feed supplement at $5 \mathrm{~g} \%$ and $10 \mathrm{gm} \%$ dose levels to the hypercholesteremic rats. Plasma and liver lipid profiles, hepatic HMG-CoA reductase, bile acid, malondialdehyde, ascorbic acid, catalase and SOD, fecal bile acid, cholesterol and neutral sterols were estimated using standard methods.

Results: Feed supplementation with $5 \mathrm{~g} \%$ and $10 \mathrm{~g} \%$ Asparagus racemosus resulted in a significant decline in plasma and hepatic lipid profiles. The feed supplementation increased the HMGCoA reductase activity and bile acid production in both groups (5 and $10 \mathrm{~g} \%$ supplemented groups) with concomitant increase in fecal bile acid and fecal cholesterol excretion. The activities of catalase, SOD and ascorbic acid content increased significantly in both the experimental groups (5 and $10 \mathrm{~g} \%$ supplemented groups). On the other hand, the concentration of malondialdehyde in these groups (5 and $10 \mathrm{~g} \%$ supplemented groups) decreased significantly, indicating decreased lipid peroxidation.

Conclusion: The present study demonstrates that addition of Asparagus racemosus root powder at $5 \mathrm{~g} \%$ and $10 \mathrm{~g} \%$ level as feed supplement reduces the plasma and hepatic lipid (cholesterol) levels and also decreases lipid peroxidation.
\end{abstract}

KEY WORDS: Feed supplement, HMG-CoA reductase, lipid profile.

\section{Introduction}

Raised serum lipid levels, particularly of cholesterol along with generation of reactive oxygen species (ROS), play a key role in the development of coronary artery disease (CAD) and atherosclerosis..$^{[1]} \mathrm{CAD}$ is a serious medical problem that affects millions of people annually throughout the world. People who are predisposed to a combination of risk factors (dietary habits, genetic susceptibility, etc.) are more prone to develop atherosclerosis and CAD. Besides stress, sedentary habits, use of tobacco and alcohol are reported to have an additive effect in contributing to development of atherosclerosis and CAD ${ }^{|2|}$ Dietary modification, physical exercise, abstinence from tobacco and alcohol, and changes in life-style have been proposed to reduce the incidence of CAD and other cardiac maladies by medical fraternity all over the world. Phytosterols and natural antioxidants have also been shown to be effective in reducing lipid profiles and also mitigate peroxidative modification of lipoproteins and atherosclerosis. ${ }^{[3]}$

Asparagus racemosus Willd. (Liliaceae), commonly known as 'satawar', satavari' or 'shatavari', has been used as antidiarrheal, antiuclerogenic, refrigerant, tonic, demulcent, diuretic, galactogogue, aphrodisiac and antispasmodic in Ayurvedia, Siddha and Unani systems of medicine. ${ }^{[4]}$ Besides, Asparagus racemosus has also been found to have antioxytocin, immunostimulant and hepatoprotective activities. ${ }^{[5], ~[6]}$

As there have been no reports on the hypocholesteremic and antiperoxidative effects of Asparagus racemosus, the present study was undertaken to evaluate its ability to reduce the cholesterol profile and it's antiperoxidative effects on body lipids.

\section{Materials and Methods}

\section{Plant material}

Fresh roots of Asparagus racemosus were harvested from Sardar Patel University Botanical garden and were dried at $37^{\circ} \mathrm{C}$ in an incubator. Then the dried roots were powdered in a mixer grinder and used as feed supplement.

Animals

Three-month-old male albino rats (Charles Foster, 
150-200 g) were selected from the animal house, Department of Biosciences, and used with the approval of Animal Ethics Committee. Animals were housed individually in a wellventilated animal unit with normal daylight. The animals were fed standard food (Pranav Agro-Industries Lid.) and water ad libitum. After a 10-day adaptation period, the animals were divided into three groups $(n=8)$ and the following treatments were given simultaneously to the concerned groups for four weeks.

Group-I: Standard diet mixed with $0.75 \mathrm{~g} \%$ cholesterol and $1.5 \mathrm{~g} \%$ bile salt to induce hypercholesteremia.

Group-II: Hypercholesteremic animals were given a $5 \mathrm{~g} \%$ Asparagus racemosus root powder as feed supplement

Group-III: Hypercholesteremic animals were given a $10 \mathrm{~g} \%$ Asparagus racemosus root powder as feed supplement.

Estimation of biochemical parameters

After the conclusion of the experiment, the animals were subjected to overnight fasting and killed under mild anesthesia.

Plasma

Blood samples were drawn by retro-orbital puncture using a fine sterile capillary tube and the plasma used for the estimation of total lipids, ${ }^{[7]}$ total cholesterol, ${ }^{[8]}$ triglycerides, ${ }^{[9]}$ HDL-cholesterol, ${ }^{[8], ~[10] ~}{ }^{10 D L-c h o l e s t e r o l, ~ V L D L-c h o l e s t e r o l ~ a n d ~}$ the atherogenic index was calculated as described by Friedewald $e t$ al. ${ }^{[11]}$ The base line plasma lipid profiles and the fecal bile acid, cholesterol and neutral sterol profiles were determined prior to the treatment regime.

Liver

Hepatic lipids were extracted ${ }^{[12]}$ and estimated gravimetrically. Total hepatic cholesterol and triglycerides were extracted $^{[12]}$ and estimated. ${ }^{[8], ~}{ }^{91]}$ HMG-CoA reductase activity was assayed by the method of Rao and Ramakrishnan and expressed as the ratio of absorbance of HMG-CoA to mevalonate. This was taken as the index of HMG-CoA reductase $^{[13]}$ activity. Hepatic bile acid was estimated by the method of Snell and Snell. ${ }^{[14]}$ Malondialdehyde, catalase, superoxide dismutase and total ascorbic acid content were assayed using standard methods. ${ }^{[15]-[19]}$

\section{Fecal matter}

Fecal bile acid, cholesterol and neutral sterols were extracted ${ }^{[20]}$ and estimated. ${ }^{[8], ~[14]}$

\section{Statistical analysis}

Statistical evaluation was done using the one-way ANOVA. Duncan's test was performed for post-hoc analysis. Differences with $\mathrm{P}<0.05$ were considered significant. Data are presented as mean $\pm \mathrm{SEM}$.

\section{Results}

\section{Plasma and hepatic lipid profiles}

A. racemosus as $5 \mathrm{~g} \%$ feed supplementation to hypercholesteremic animals resulted in a decrease of total lipids (29\%), total cholesterol (29\%), triglycerides (39\%), LDLcholesterol (33\%), VLDL-cholesterol (39\%), atherogenic index (37\%) and an increase in HDL-cholesterol content (11\%). With $10 \mathrm{gm} \%$ A. racemosus treatment, a further reduction occurred in total lipids $(64 \%)$, total cholesterol (38\%), triglycerides (52\%), LDL-cholesterol (44\%), VLDL-cholesterol (52\%) and atherogenic index (49\%). This reduction in total lipids, total cholesterol, triglycerides, LDL-, VLDL- cholesterol and atherogenic index was dose-dependent and significant. A further increase in HDL-cholesterol (21\%) level was also noted as compared to Group-II animals. [Table 1] A. racemosus also reduced total lipids ( $26 \%$ and $36 \%$, respectively), total cholesterol ( $46 \%$ and $57 \%$, respectively) and triglycerides (38\% and $57 \%$, respectively) in the liver of treated groups as compared to control. [Table 2]

\section{Cholesterol metabolism and excretion}

A significant increase in hepatic HMG-CoA reductase activity was noted in Group-II (27\%) and Group-III (37\%) compared to the control hypercholesteremic animals. The

Table 1

Effect of Asparagus racemosus (root powder) on plasma lipid profiles in rats

\begin{tabular}{|c|c|c|c|c|c|c|c|c|}
\hline Plasma & Treatment & $T L$ & $T C$ & $T G$ & $H D L-C$ & $L D L-C$ & $V L D L-C$ & $A I$ \\
\hline $\begin{array}{l}\text { Baseline } \\
\text { Values* }\end{array}$ & - & $505.37 \pm 8.94$ & $128.92 \pm 2.58$ & $60.40 \pm 2.33$ & $71.87 \pm 0.88$ & $45.04 \pm 2.80$ & $12.00 \pm 0.80$ & $1.79 \pm 0.03$ \\
\hline Group-I & $\mathrm{HC}$ & $\begin{array}{c}1444.16 \pm 20.64^{a} \\
\quad(+185.76)\end{array}$ & $\begin{array}{c}505.64 \pm 11.5^{a} \\
(+292.21)\end{array}$ & $\begin{array}{c}149.38 \pm 8.18^{b} \\
(+148.80)\end{array}$ & $\begin{array}{c}49.95 \pm 1.74^{c} \\
(-30.49)\end{array}$ & $\begin{array}{c}425.82 \pm 10.07^{a} \\
\quad(+845.42)\end{array}$ & $\begin{array}{l}29.87 \pm 1.63^{b} \\
(+148.91)\end{array}$ & $\begin{array}{c}10.17 \pm 0.29^{a} \\
(+468.15)\end{array}$ \\
\hline Group-II & HAR5 & $\begin{array}{c}1030.83 \pm 27.93^{b} \\
\quad(-28.62)\end{array}$ & $\begin{array}{c}358.08 \pm 9.50^{\mathrm{b}} \\
(-29.18)\end{array}$ & $\begin{array}{c}91.55 \pm 7.27^{c} \\
(-38.71)\end{array}$ & $\begin{array}{c}55.65 \pm 1.19^{\mathrm{b}} \\
(+11.41)\end{array}$ & $\begin{array}{c}284.12 \pm 10.08^{b} \\
\quad(-33.27)\end{array}$ & $\begin{array}{c}18.30 \pm 1.45^{\circ} \\
(-38.73)\end{array}$ & $\begin{array}{l}6.44 \pm 0.18^{b} \\
(-36.67)\end{array}$ \\
\hline Group-III & HAR10 & $\begin{array}{c}519.16 \pm 10.90^{c} \\
\quad(-64.05)\end{array}$ & $\begin{array}{c}315.23 \pm 9.11^{c} \\
(-37.65)\end{array}$ & $\begin{array}{c}70.90 \pm 6.43^{c} \\
(-52.47)\end{array}$ & $\begin{array}{c}60.51 \pm 0.52^{\mathrm{a}} \\
(+21.14)\end{array}$ & $\begin{array}{c}240.52 \pm 10.11^{c} \\
\quad(-43.51)\end{array}$ & $\begin{array}{c}14.19 \pm 1.28^{c} \\
(-52.49)\end{array}$ & $\begin{array}{c}5.21 \pm 0.17^{c} \\
(-48.77)\end{array}$ \\
\hline One-way & $\mathrm{F}$ & 488.737 & 98.135 & 30.622 & 17.747 & 30.848 & 92.677 & 131.819 \\
\hline ANOVA & df & 2,21 & 2,21 & 2,21 & 2,21 & 2,21 & 2,21 & 2,21 \\
\hline & $P$ & 0.0001 & 0.0001 & 0.0001 & 0.0001 & 0.0001 & 0.0001 & 0.0001 \\
\hline
\end{tabular}

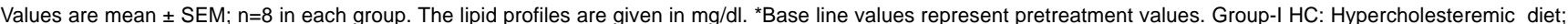

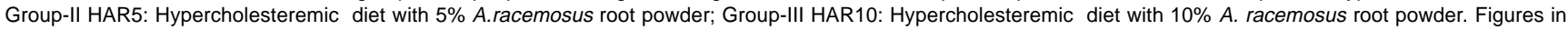

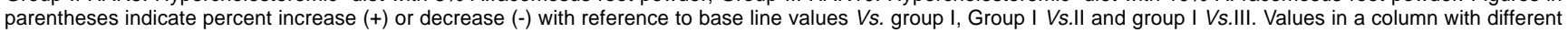

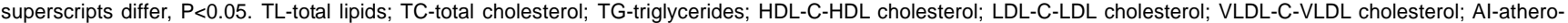
genic index. 
Table 2

Effect of Asparagus racemosus (root powder) on hepatic lipid profiles in rats

\begin{tabular}{lcccc}
\hline \multirow{2}{*}{ Liver } & \multirow{2}{*}{ Treatment } & \multicolumn{1}{c}{ TC } & TG \\
\cline { 3 - 5 } & & \multicolumn{3}{c}{$\mathbf{m g} / \boldsymbol{g}$} \\
\hline Group-I & HC & $97.87 \pm 4.71^{\mathrm{b}}$ & $25.51 \pm 1.56^{\mathrm{b}}$ & $22.35 \pm 0.86^{\mathrm{a}}$ \\
Group-II & HAR5 & $72.37 \pm 3.91^{\mathrm{c}}$ & $13.66 \pm 0.84^{\mathrm{c}}$ & $13.85 \pm 0.50^{\mathrm{b}}$ \\
& & $(-26.05)$ & $(-46.45)$ & $(-38.03)$ \\
Group-III & HAR10 & $62.50 \pm 2.91^{\mathrm{c}}$ & $10.93 \pm 0.86^{\mathrm{c}}$ & $9.63 \pm 1.08^{\mathrm{c}}$ \\
& & $(-36.13)$ & $(-57.15)$ & $(-56.91)$ \\
\hline One-way & $\mathrm{F}$ & 21.825 & 46.338 & 57.924 \\
ANOVA & df & 2,21 & 2,21 & 2,21 \\
& $\mathrm{P}$ & 0.0001 & 0.0001 & 0.0001 \\
\hline
\end{tabular}

Values are mean \pm SEM; $n=8$ in each group. Group-I HC: Hypercholesteremic diet; Group-II HAR5: Hypercholesteremic diet with 5\% A.racemosus root Powder; Group-III HAR10: Hypercholesteremic diet with 10\% A.racemosus root powder. Figures in parentheses indicate percent increase $(+)$ or decrease (-). Comparisons for percentage were taken between. Groups I Vs.II and I Vs.III. Values in a column with different superscripts differ, $\mathrm{P}<0.05$. TL-total lipids; TCtotal cholesterol; TG-triglycerides hepatic bile acid production also increased [Table 3] in treated groups (12\% and $25 \%$, respectively). The fecal cholesterol metabolites excretion, such as bile acid $(31 \%$ and $25 \%$, respectively), cholesterol (14\% and $28 \%$, respectively) and neutral sterols (8\% and $5 \%$, respectively) increased in $A$. racemosus treated groups compared to control. [Table 4]

Antioxidant activities in hepatic tissue

The hepatic lipid peroxidation (malondialdehyde content) decreased significantly in $A$. racemosus treated groups $(21 \%$ and $20 \%$, respectively) when compared to control. The activities of catalase and superoxide dismutase also increased in both experimental groups (II and III 34\%, 34\% and 17\%, 18\%, respectively) as compared to the hypercholesteremic groups. The hepatic ascorbic acid content of both experimental groups (II and III) also exhibited a similar increase (25\% and 24\%, respectively) when compared to the values obtained for GroupI. [Table 5]

\section{Discussion}

Addition of $A$. racemosus dried root powder as a feed supplement at two levels, i.e., $5 \mathrm{~g} \%$ and $10 \mathrm{~g} \%$, resulted in a dose-dependent reduction in lipid profiles in plasma and liver along with significant reduction in lipid peroxidation. The total lipids, total cholesterol and triglycerides in plasma and liver as well as plasma LDL- and VLDL-cholesterol were significantly reduced at both doses of feed supplementation. However, HDLcholesterol level increased in both treated groups significantly. This observation indicates that $A$. racemosus root powder, as a feed component is effective in reducing plasma LDL- and VLDL-cholesterol levels. It is well known that increased HDLcholesterol levels have a protective role in CAD. ${ }^{[21]}$ The decreased hepatic lipids including cholesterol and triglycerides in treated animals along with increased bile acid, cholesterol and neutral sterols content in fecal matter indicate that A.racemosus may reduce the absorption of dietary cholesterol
Table 3

Effect of Asparagus racemosus on the activity of HMG-CoA reductase and bile acid content in liver

\begin{tabular}{lccc}
\hline Liver & Treatment & $\begin{array}{c}\text { HMG-CoA } \\
\text { reductase* }\end{array}$ & $\begin{array}{c}\text { Bile acid } \\
(\mathbf{m g} / \mathbf{g})\end{array}$ \\
\hline Group-I & HC & $5.26 \pm 0.34^{\mathrm{b}}$ & $4.06 \pm 0.12^{\mathrm{c}}$ \\
Group-II & HAR5 & $3.82 \pm 0.34^{\mathrm{c}}$ & $4.54 \pm 0.11^{\mathrm{b}}$ \\
Group-III & HAR10 & $3.31 \pm 0.12^{\mathrm{c}}$ & $(+11.82)$ \\
& & $(+37.07)$ & $5.09 \pm 0.20$ \\
One-way & $\mathrm{F}$ & 11.949 & $(+25.36)$ \\
ANOVA & $\mathrm{df}$ & 2,21 & 11.097 \\
& $P$ & 0.0001 & 2,21 \\
& & & 0.001
\end{tabular}

*HMG-CoA reductase activity is expressed as the ratio of $\mathrm{HMG}-\mathrm{Co} A /$ Mevalonate and its activity is inversely proportional to the ratio HMG CoA/Mevalonate. Values are mean $\pm S E M ; n=8$ in each group. Group-I HC: Hypercholesteremic diet; Group-II HAR5: Hypercholesteremic diet with 5\% A.racemosus root powder; Group-III HAR10: Hypercholesteremic diet with $10 \%$ A.racemosus root powder. Figures in parentheses indicate percent increase (+) or decrease (-); Comparisons for percentage were taken between Groups I Vs.II and I Vs.III. Values in a column with different superscripts differ, $\mathrm{P}<0.05$.

\section{Table 4}

Effect of Asparagus racemosus on bile acid, cholesterol and neutral sterols of fecal matter

\begin{tabular}{lcccc}
\hline Fecal & Treatment & $\begin{array}{c}\text { Bile } \\
\text { acid }\end{array}$ & Cholesterol & $\begin{array}{c}\text { Neutral } \\
\text { sterols }\end{array}$ \\
\cline { 3 - 5 } & & \multicolumn{3}{c}{$\mathbf{m g} / \mathbf{g}$} \\
\hline Baseline & - & $4.65 \pm 0.08$ & $0.36 \pm 0.01$ & $5.01 \pm 0.05$ \\
Group-I & HC & $10.90 \pm 0.62^{\mathrm{c}}$ & $4.10 \pm 0.15^{\mathrm{c}}$ & $13.77 \pm 0.42^{\mathrm{c}}$ \\
& & $(+134.40)$ & $(+1038.88)$ & $(+174.85)$ \\
Group-II & HAR5 & $14.32 \pm 0.68^{\mathrm{b}}$ & $4.68 \pm 0.17^{\mathrm{b}}$ & $14.88 \pm 0.42^{\mathrm{c}}$ \\
& & $(+31.37)$ & $(+14.14)$ & $(+8.06)$ \\
Group-III & HAR10 & $13.65 \pm 0.64^{\mathrm{b}}$ & $5.23 \pm 0.10^{\mathrm{a}}$ & $14.52 \pm 0.71^{\mathrm{c}}$ \\
& & $(+25.22)$ & $(+27.56)$ & $(+5.44)$ \\
\hline One-way & $\mathrm{F}$ & 7.785 & 14.096 & 1.103 \\
ANOVA & $\mathrm{df}$ & 2,21 & 2,21 & 2,21 \\
& $\mathrm{P}$ & 0.01 & 0.0001 & $\mathrm{NS}$ \\
\hline
\end{tabular}

Values are mean \pm SEM; *Baseline values are the values obtained prior to treatments. Group-I HC: Hypercholesteremic diet; Group-II HAR5: Hypercholesteremic diet with $5 \%$ A.racemosus root. Powder; Group-III HAR10: Hypercholesteremic diet with $10 \%$ A.racemosus root powder. Figures in parentheses indicate percent increase $(+)$ or decrease $(-)$ with reference to base line values Vs. group I, group I Vs.II and group I Vs.III. Values in a column with different superscripts differ, $\mathrm{P}<0.05$

and enhance it's excretion. A similar result was reported when soy protein was used as feed supplement. ${ }^{1221}$ The increased HMG CoA reductase activity noted in both experimental groups (II and III) as compared to control could be due to an increased cholesterol excretion and decreased cholesterol absorption through the gastrointestinal tract. Thus the decreasing cholesterol levels in the body under the influence of A.racemosus could have enhanced the enzymatic activity by a positive feedback mechanism. Further, increased bile acid 
Concentrations of malondialdehyde (MDA), total ascorbic acid and activities of catalase and superoxide dismutase in liver

\begin{tabular}{|c|c|c|c|c|c|}
\hline Liver & Treatment & $\begin{array}{l}\text { Lipid peroxidation } \\
\text { nm } M D A / g\end{array}$ & $\begin{array}{c}\text { Total ascorbic acid } \\
\mu / g\end{array}$ & $\begin{array}{c}\text { Catalase } \\
\mathrm{nm} \mathrm{H}_{2} \mathrm{O}_{2} \text { decomposed/ } \\
\text { sec } / \mathrm{g}\end{array}$ & $\begin{array}{c}\text { Superoxide dismutase } \\
\text { unit /mg protein }\end{array}$ \\
\hline Group-I & $\mathrm{HC}$ & $22.58 \pm 0.61^{\mathrm{b}}$ & $42.76 \pm 0.43^{c}$ & $12.82 \pm 0.49^{c}$ & $3.04 \pm 0.10^{c}$ \\
\hline Group-II & HAR5 & $\begin{array}{c}17.91 \pm 0.65^{c} \\
(-20.68)\end{array}$ & $\begin{array}{l}53.62 \pm 0.90^{b} \\
(+25.39)\end{array}$ & $\begin{array}{l}17.20 \pm 0.50^{b} \\
\quad(+34.16)\end{array}$ & $\begin{array}{c}3.57 \pm 0.08^{b} \\
(+17.43)\end{array}$ \\
\hline Group-III & HAR10 & $\begin{array}{c}17.98 \pm 0.42^{c} \\
(-20.37)\end{array}$ & $\begin{array}{c}53.17 \pm 0.86^{b} \\
(+24.34)\end{array}$ & $\begin{array}{c}17.24 \pm 0.44^{b} \\
(+34.47)\end{array}$ & $\begin{array}{l}3.60 \pm 0.10^{\mathrm{b}} \\
(+18.42)\end{array}$ \\
\hline One-way & $\mathrm{F}$ & 21.698 & 64.085 & 27.800 & 9.046 \\
\hline \multirow[t]{2}{*}{ ANOVA } & df & 2,21 & 2,21 & 2,21 & 2,21 \\
\hline & $P$ & 0.0001 & 0.0001 & 0.0001 & 0.001 \\
\hline
\end{tabular}

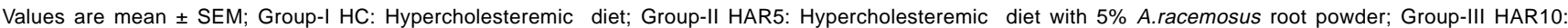

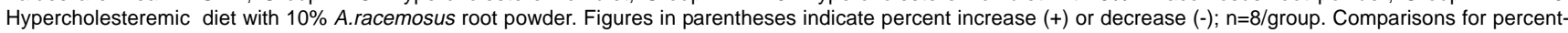
age were taken between Groups I Vs.II and I Vs.III. Values in a column with different superscripts differ, $\mathrm{P}<0.05$.

production also indicates the turnover of endogenous cholesterol into bile acid that could be under the influence of supplementary feeding with A.racemosus. A similar modulator activity was observed when guar gum was used as feed supplement. ${ }^{[23]}$

Hypercholesteremia, high cholesterol diet and oxidative stress increase serum LDL levels resulting in increased risk for development of atherosclerosis. ${ }^{[24]}$ Besides, malondialdehyde a secondary product of lipid peroxidation is a major reactive aldehyde; higher levels can lead to peroxidation of biological membranes. ${ }^{\mid 25]}$ The antioxidant enzymes, mainly superoxide dismutase and catalase are first line defensive enzymes against free radicals and, ascorbic acid is also known to control oxidative damage. ${ }^{[26]}$ The present work shows that the A.racemosus treated groups have higher levels of antioxidative parameters (ascorbic acid, catalase and superoxide dismutase) and decreased level of lipid peroxidation indicating its efficacy to reduce the LDL-cholesterol oxidation. The quantitative analysis of $A$. racemosus root powder indicated the presence of flavonoids, polyphenols and ascorbic acid $(4.7 \pm 0.32 \mathrm{mg} / \mathrm{g}, 16.9 \pm 1.1 \mathrm{mg} / \mathrm{g}$ and $7.6 \pm 0.06 \mathrm{mg} / \mathrm{g}$, respectively, our unpublished data). It is well known that flavonoids and polyphenols are natural antioxidants but have also been reported to significantly increase SOD and catalase activities. ${ }^{[27 \mid-[34]}$ Further, it was shown that these compounds act as promoters for SOD and catalase ${ }^{[31]}$ and cause the expression of SOD and catalase. ${ }^{[3]}$ The currently noted elevated levels of both SOD and catalase with A.racemosus root powder could be due to the influence of flavonoids and polyphenols . A significantly elevated ascorbic acid content in the hepatic tissues of treated groups due to dietary supplementation with A.racemosus root powder could have reduced the hepatic MDA levels leading to a significant decrease in lipid peroxidation. ${ }^{[26]}$

To conclude, feed supplementation with $A$. racemosus dried root powder reduced the hyperlipidemic and hypercholesteremic conditions. A. racemosus appeared to ameliorate hypercholesteremia probably by decreasing the exogenous cholesterol absorption and increasing the endogenous cholesterol conversion to bile acid, though to know the exact mechanism further studies are needed.

\section{References}

1. Ross R. Atherosclerosis: An inflammatory disease. N Eng J Med 1999;340:11526.

2. Ashakumary A, Vijayammal PL. Additive effect of alcohol and nicotine on lipid metabolism in rats. Indian J Exp Biol 1993;31:270-4.

3. Ikeda I, Sugano M. Inhibition of cholesterol absorption by plant sterols for mass intervention. Curr Opin Lipido 1998;9:527-31.

4. Kapoor LD. Hand book of Ayurvedic medicinal plants. Herbal Reference Library Edition. New York: CRC Press; 2001.

5. Ravikumar PR, Soman R, Chetty GL, Pandey RC, Sukh Dev. Chemistry of Ayurvedic crude drugs: Part VI-(Shatavari-I). Structure of Shatavarin -IV. Indian J Chem 1987;26:1012-7.

6. Maruganandan S, Garg H, Lal J, Chandra S, Kumar D. Studies on the immunostimulant and antihepatotoxic activities of Asparagus racemosus root extract. J Med Arom Plant Sci 2001;23:49-51.

7. Fringe CS, Fendley TW, Dunn RT, Owen CA. Improved determination of total serum lipids by sulphosphovanillin reaction. Clin Chem 1972;18:673-4.

8. Wybenga DR, Pileggi VJ, Dirstine PH, Di Glorgio J. Direct manual determination of serum total cholesterol with a single stable reagent. Clin Chem 1970;16: 980-4.

9. Mc Gown MW, Artiss JD, Strandbergh DR, Zak B. A peroxidase-coupled method for the colorimetric determination of serum triglycerides. Clin Chem 1983;29:538-42.

10. Burstein M, Scholnic HR, Morfin R. Rapid method for the isolation of lipoproteins from human serum by precipitation with polyanion. J Lipid Res 1970;11:583-95.

11. Friedewald WT, Levy RT, Fredrickson DS. Estimation of the concentration of low-density lipoprotein cholesterol in plasma without use of the preparative ultracentrifuge. Clin Chem 1972;18:499-502.

12. Folch J, Lees M, Sloane Stanley GH. A simple method for the isolation and purification of total lipids from animal tissues. J Biol Chem 1957;226:497-509.

13. Rao AV, Ramakrishnan S. Indirect assessment of hydroxy-methylglutaryl-CoA reductase (NADPH) activity in liver tissue. Clin Chem 1975;21:1523-5.

14. Snell FD, Snell CT. Colorimetric Methods of Analysis. 3 ed. Vol. 3. Canada: D.Van no Strand Company, Inc.; 1953.

15. Niehaus Jr. WG, Samuelsson B. Formation of malondialdehyde from phospholipids arachidonate during microsomal lipid peroxidation. Europ $\mathrm{J}$ Biochem 1968;6:126-30.

16. Cohen G. Dembiec D. Marcus J. Measurement of catalase activity in tissue extract. Anal Biochem 1970;34:30-8.

17. Aebi H. Methods of Enzymatic Analysis. 2 ed. Vol. 2. (Ed Bergmeyer). New York: Academic Press; 1974. 
18. Kakkar P, Das B, Viswanathan PN. A modified spectrophotometric assay of superoxide dismutase. Indian J Biochem Biophy 1984;21:130-2.

19. Schaffert RR, Kingsley GR. A rapid simple method for the determination of reduced, dehydro, and total ascorbic acid in biological material. J Bio Chem 1955;212:59-68.

20. Kalek HD, Stellaard F, Kruis W, Paumgartner G. Detection of increase bile acid excretion by determination of bile acid content in simple stool samples. Clin Chem Acta 1984;140:85-90.

21. Wilson PW, Abbott RD, Castelli WP. High density lipoprotein cholesterol and mortality. The Framingham heart study. Arterioscler Thromb Vasc Biol 1988;8: 737-41.

22. Lin Y, Meijer GW, Mario A, Vermeer, Trautwein EA. Soy protein enhances the cholesterol-lowering effect of plant sterol esters in cholesterol-fed hamsters. J Nutr 2004;134:143-8.

23. Moundras C, Behr SR, Remesy C, Demigne C. Fecal losses of sterols and bile acids induced by feeding rats guar gum are due to greater pool size and liver bile acid secretion. J Nutr 1997;127:1068-76.

24. Warnholtz A, Mollnau H, Oelze M, Wendt M, Munzel T. Antioxidants and endothelial dysfunction in Hyperlipidemia. Curr Hypertension Reports 2001;3: 53-60.

25. Tiwari AK. Natural product antioxidants and their therapeutic potential in mitigating peroxidative modification of lipoproteins and atherosclerosis: recent development. J Med Arom Plant Sci 1999;21:730-41.

26. Parthasarathy S, Santanam N, Ramachandran S, Meilhac O. Oxidant and antioxidants in atherogenesis: an appraisal. J Lipid Res 1999;40:2143-57.

27. Fang YZ, Yang S, Wu G. Free radicals, Antioxidants and Nutrition. Nutrition 2002;18:872-9.

28. Badami S, Gupta MK, Suresh B. Antioxidant activity of the ethanolic extract of Striga orobanchioides. J Ethanopharmocol 2003;85:227-30.

29. Frei B, Higdon JV. Antioxidant activity of tea polyphenols in vivo: Evidence from animal studies. J Nutr 2003;133:3275-84.

30. Soto C, Recoba R, Barron H, Alvarez C, Favari L. Silymarin increases antioxidant enzymes in alloxan induced diabetes in rat pancreas. Comp Biochem Physiol C Toxicol Pharmacol 2003;136:205-12.

31. Toyokuni S, Tanaka T, Kawaguchi W, Fang NR, Ozeki M, Akatsuka S, et al. Effects of the phenolic contents of Mauritian endemic plant extracts on promoter activities of antioxidant enzymes. Free Radic Res 2003;37:121524.

32. Jung SH, Lee YS, Lim SS, Lee S, Shin KH, Kim YS. Antioxidant activities of isoflavones from the rhizomes of Belamcanda chinensis on carbon tetrachloride induced hepatic injury in rats. Arch Pharm Res 2004;27:184-8.

33. Ranaivo HR, Rakotoarison O, Tesse A, Schott C, Randriantsoa A, Lobstein A, et al. Cedrelopsis grevei induced hypotension and improved endothelial vasodialation through an increase of $\mathrm{Cu} / \mathrm{Zn} \mathrm{SOD}$ protein expression. Am J Physiol Heart Circ Physiol 2004;286:775-81.

34. Sudheesh S, Vijayalakshmi NR. Flavonoids from Punic granatum- potential antiperoxidative agents. Fitoterapia 2005;76:181-6.

\section{HOW TO KILL A SOCIETY}

1. Do not go to meetings - let "them" handle things. Then complain that members have no voice in the management.

2. If you go, arrive late and limit your remarks to destructive comments.

3. Don’t pay your dues. Don’t participate in membership drive.

4 Decline offices or appointments. But become indignant if you are not nominated or appointed.

5. If you are appointed or elected, fail to attend meetings. When you do attend a meeting, pretend to be active, volunteer for something, then forget all about it after the meeting.

6. Refuse to speak out, and then complain that no one listens to you and you have learnt nothing.

7. Don't read the organization's newsletter. Then complain that you're never kept informed.

8. Don't volunteer your talents - that's ego fulfillment. Then complain that you're never asked and never appreciated.

9. Do not work if you can avoid it. When others roll up their sleeves and do their very best, complain that the association is run by a group of ego trippers.

8. Oppose all banquets, parties, and social events as being a waste of members' money.

9. When everything is strictly business, complain that meetings are dull and the organizers a bunch of old sticks.

10. Complain that the official publication is of low standard but submit your good quality work to foreign journals.

11. When the society dies say you saw it coming years before.

And, if by chance the organization grows in spite of your contributions, grasp every opportunity to tell the youngsters how tough it was and how hard you worked in the old days to bring the organization to it's present level of success. 